\title{
The heat transport of the Indonesian Throughflow and implications for the Indian Ocean heat budget
}

\author{
Kevin Vranes ${ }^{\mathrm{a}, \mathrm{b}, *}$, Arnold L. Gordon ${ }^{\mathrm{a}, \mathrm{b}}$, Amy Ffield ${ }^{\mathrm{a}}$ \\ ${ }^{a}$ Lamont-Doherty Earth Observatory of Columbia University, 202E Oceanography, Palisades, NY 10964, USA \\ ${ }^{\mathrm{b}}$ Department of Earth and Environmental Science, Columbia University, New York, NY 10027, USA
}

Accepted 16 September 2001

\begin{abstract}
The Indonesian Throughflow (ITF) is considered central to the heat budgets of the Pacific and Indian Oceans. Temperature and ocean current time series obtained within the Makassar Strait from December 1996 to early July 1998 are used to calculate heat transport of the ITF and assess its influence on Indian Ocean heat divergence. Velocity and temperature values for the surface layer that were not directly measured are extrapolated from the shallowest measurement to the sea surface using a variety of model profiles. While a single temperature profile is used based on a linear interpolation from NCEP OI sea-surface temperatures to the top-most mooring temperature recorder, four different velocity profiles are employed. Heat transport is calculated as volume transport multiplied by temperature, density and specific heat, using reference temperatures between $0^{\circ} \mathrm{C}$ and $4{ }^{\circ} \mathrm{C}$. The mean heat transport averages $0.55 \mathrm{PW}$ relative to $0^{\circ} \mathrm{C}$, and $0.41 \mathrm{PW}$ relative to $4^{\circ} \mathrm{C}$ for the two most reasonable velocity profiles. In comparison, model heat transport values are larger, between 0.6 and $1.15 \mathrm{PW}$. Heat transport varies with ENSO phase, lower during El Niño, higher during La Niña. As 1997 was a strong El Niño year, our heat transport estimate may be less than the climatic mean. The ITF water is advected towards Africa within the Indian Ocean South Equatorial Current, to eventually exit the Indian Ocean across $30^{\circ} \mathrm{S}$, most likely within the Agulhas Current. For realistic consideration of the ITF component within the Agulhas Current, the heat flux divergence of ITF waters within the Indian Ocean north of $30^{\circ} \mathrm{S}$ is found to be insignificant. Our results provide support for model studies and hydrographic geostrophic inverse calculations that indicate the ITF heat, derived from the Pacific Ocean, is ultimately lost to the atmosphere in the southwest Indian Ocean. (C) 2002 Elsevier Science Ltd. All rights reserved.
\end{abstract}

\section{Introduction}

The Indonesian seas provide a pathway for substantial transfer of Pacific Ocean waters to the Indian Ocean (Rochford, 1961; Wyrtki, 1961;

*Corresponding author. Tel.: + 1-845-365-8576; fax: + 1845-365-8157.

E-mail address: kvranes@ldeo.columbia.edu (K. Vranes).
Gordon, 1986; Wyrtki, 1987). The Indonesian Throughflow (ITF) strongly influences the heat and freshwater budgets of these two oceans and therefore may be considered a key component in the ENSO and monsoon climate phenomena (see the reviews of Godfrey, 1996; Lukas et al., 1996; Webster et al., 1998). The meridional circulation, stratification, sea-surface temperature and sea level of both oceans would be substantially altered if the ITF were zero (e.g. Hirst and Godfrey, 1993; 
Macdonald, 1993; Verschell et al., 1995; Schneider and Barnett, 1997).

Large-scale observation based studies (including inverse solutions) reveal significant Pacific export of freshwater and heat into the Indian Ocean (Piola and Gordon, 1984; Toole and Raymer, 1985; Wijffels et al., 1992; Macdonald, 1993; Toole and Warren, 1993; Macdonald and Wunsch, 1996; Robbins and Toole, 1997; Ganachaud et al., 2000). Increased oceanic heat and freshwater flux into the Indian Ocean at the expense of the Pacific affects atmosphere-ocean coupling with potential impacts on the ENSO and monsoon phenomena. Webster et al. (1998) state that the heat flux of the ITF is comparable to the net surface flux over the northern Indian Ocean and is a substantial fraction of the heat flux into the western Pacific warm pool.

Indonesian Throughflow waters are chiefly drawn from the North Pacific thermocline and intermediate water, with South Pacific water contributing to the lower thermocline and deeper layers within the Indonesian seas (Fine, 1985; Gordon and Fine, 1996; Hautala et al., 1996; Ilahude and Gordon, 1996). The primary path of the ITF is through Makassar Strait (Fig. 1; Ffield and Gordon, 1992; Gordon et al., 1999), consistent with Wajsowicz (1996) model results that show that the westernmost deep channel, Makassar Strait, carries the bulk of ITF water. Water masses indicate no significant return to the Pacific Ocean of Makassar Strait water along a route east of Sulawesi Island, indicating that Makassar transport feeds into the ITF (Gordon and Fine, 1996).

ITF transport estimates range from near zero to $30 \mathrm{~Sv}$ (see the review of Godfrey (1996) and subsequent papers: Molcard et al., 1996; Gordon et al., 1997; Potemra et al., 1997; Schneider and Barnett, 1997; Shriver and Hurlburt, 1997; Gordon and McClean, 1999; Gordon et al., 1999; Ganachaud and Wunsch, 2000; Molcard et al., 2001). Model research suggests that the ITF is a response to the large-scale wind field over the Pacific Ocean and the longshore wind component along western Australia (the Island Rule; e.g., Godfrey, 1989, 1996; Godfrey and Ridgway, 1985). Measurements in the Lombok Strait (Murray and Arief, 1988) from January 1985 to January
1986 show an average transport of $1.7 \mathrm{~Sv}$. The mean transport between the sea surface and $1250 \mathrm{~m}$ in the Timor Passage (south of Timor Island) measured in March 1992-April 1993 is 4.3 Sv (Molcard et al., 1996). Molcard et al. (2001) find a range of transport within Ombai Strait (north of Timor Island) during 1996 of 3-6 Sv, depending on the assumed cross-strait shear. While caution is urged as these time series measurements are not made concurrently, Makassar Strait transport is comparable to the transport sum through the passages of the Lesser Sunda Island chain (the island chain east of Java along $8.5^{\circ} \mathrm{S}$ ) of $10 \mathrm{~Sv}$ (Gordon, 2001). This is also consistent with estimates of the ITF contribution to the South Equatorial Current in the Indian Ocean (Gordon et al., 1997).

Observational and model studies suggest the ITF transport varies (by as much as $\pm 5 \mathrm{~Sv}$ ) with the phase of ENSO: larger transport during La Niña, smaller transport during El Niño (Bray et al., 1996; Fieux et al., 1996; Gordon and Fine, 1996; Meyers, 1996; Potemra et al., 1997). The highresolution POP model (Gordon and McClean, 1999) yields a $12 \mathrm{~Sv}$ annual average during $\mathrm{La}$ Niña and $4 \mathrm{~Sv}$ average during El Niño. The Arlindo mooring observations within Makassar Strait (Gordon et al., 1998; Gordon and Susanto, 1999; Gordon et al., 1999), which cover the strong $1997 / 1998$ El Niño, find a correlation $(r=0.73)$ between Makassar transport and ENSO. During the El Niño months December 1997 to February 1998 the transport average is $5.1 \mathrm{~Sv}$, while during the La Niña months of December 1996 to February 1997 the average is $12.5 \mathrm{~Sv}$ (Gordon et al., 1999). With the ENSO effect removed, most of the remaining variance of ITF transport is explained by the annual cycle, with a June maximum and December minimum (Gordon et al., 1999), and by intraseasonal events (Qiu et al., 1999; Sprintall et al., 2000; Susanto et al., 2000). Potemra (1999) performs an intercomparison study of a $1 \frac{1}{2}$ - layer, reduced-gravity model to investigate the forcing mechanisms of the ITF on annual timescales. His results show a June maximum and December minimum in ITF transport with an $8 \mathrm{~Sv}$ annual cycle. Using the Hadley Centre HadCM3 model, Banks (2000) finds a 


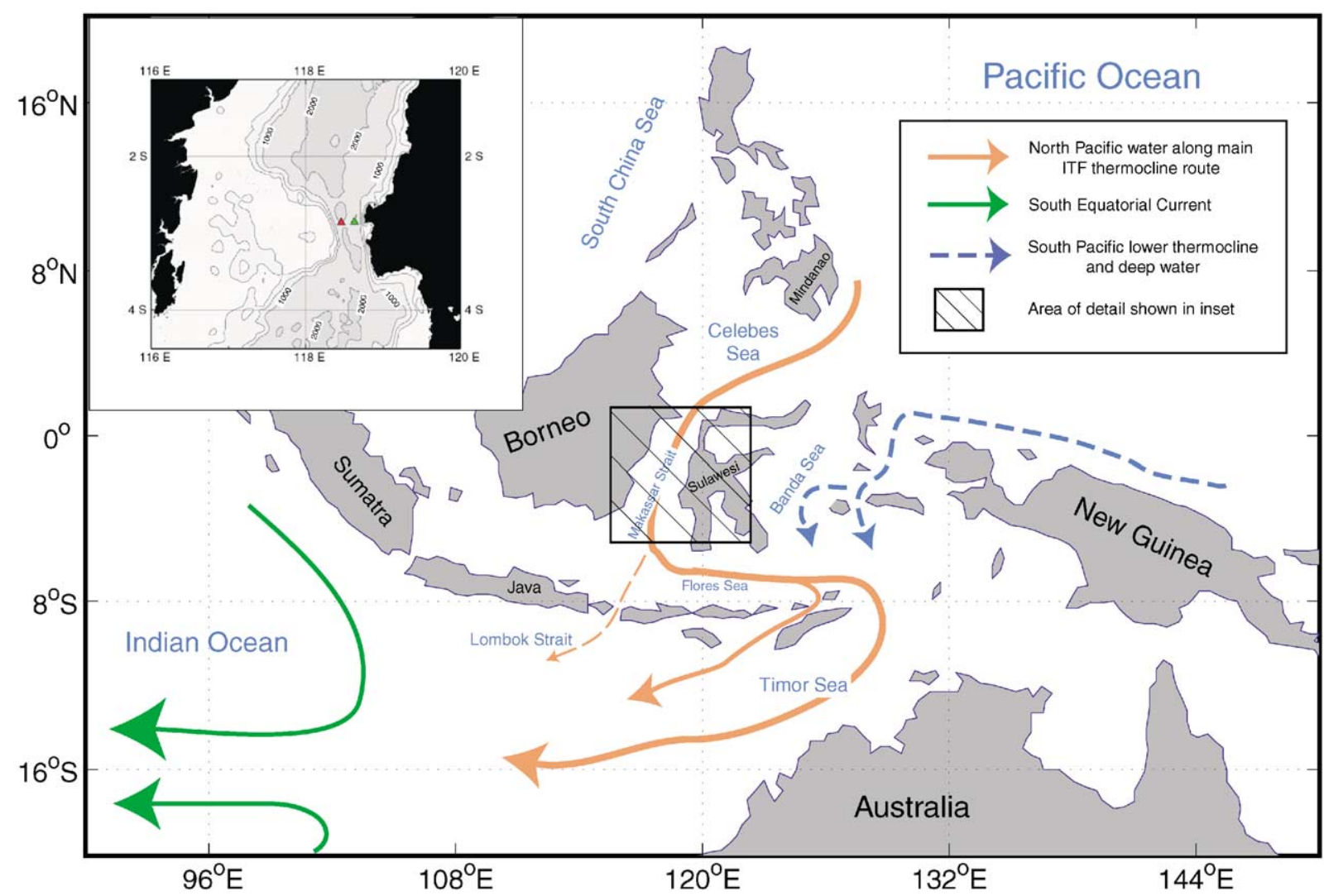

Fig. 1. Interocean throughflow of the Indonesian Seas. Inset shows position of the MAK-1 (December 1996-July 1998, red symbol) and MAK-2 (December 1996-February 1998, green symbol) moorings with local bathymetry; $1000 \mathrm{~m}$ and $2000 \mathrm{~m}$ isobaths shown.

September maximum and January minimum with total throughflow of $\mathrm{O}(24) \mathrm{Sv}$, towards the high end of published estimates.

In this study we use the Arlindo Makassar Strait mooring time series to calculate the ITF heat transport within Makassar Strait and to estimate a range of the possible heat loss of ITF water to the atmosphere over the Indian Ocean north of $30^{\circ} \mathrm{S}$. (Although Warren (1999) correctly argues that the term "internal energy transport" is more appropriate than the term "heat transport", we will follow common convention with use of "heat transport" (also see Ganachaud et al., 2000).) Many numerical models investigate the difference between zero and finite ITF on the sea-air heat flux within the Indian Ocean. Our objective in estimating the ITF heat divergence is to provide a parallel value to the model studies while acknowl- edging an inability to evaluate the precise pathway of water transport and heat exchange of the ITF within the Indian Ocean. We attempt to do so by comparing the ITF heat input to a reasonable approximation of the state of the ITF waters upon leaving the Indian Ocean at $30^{\circ} \mathrm{S}$ within the Agulhas Current. The heat divergence that we calculate within the Indian Ocean (north of $30^{\circ} \mathrm{S}$ ) is due solely to ITF heat introduced to the Indian Ocean.

An initial estimate of the heat transport (Warren, 1999) using the Arlindo mooring data (Fig. 1) for the Makassar Strait is made by Ffield et al. (2000) by integrating the product of temperature, volume transport, density and specific heat in the upper $400 \mathrm{dbar}$ of the water column. The temperature field is constructed from discrete thermocline temperature measurements 
and mean water column temperatures estimated from Inverted Echo Sounder travel times. The initial estimate of the 1997 Makassar Strait heat transport is $0.50 \mathrm{PW}\left(1 \mathrm{PW}=10^{15} \mathrm{~W}\right)$, referenced to $0^{\circ} \mathrm{C}$. Model studies estimate ITF heat transport between 0.66-1.15 PW (Hirst and Godfrey, 1993; Schneider and Barnett, 1997; Schiller et al., 1998; Gordon and McClean, 1999; Lebedev and Yaremchuk, 2000). Ganachaud et al. (2000), using inverse techniques, calculates ITF heat transport of $1.36 \pm 0.15 \mathrm{PW}$ across a section from Bali, Indonesia to NW Australia near $115^{\circ} \mathrm{E}$.

\section{Data}

\subsection{Makassar Strait}

From November 1996 to July 1998, two moorings obtained ocean current, temperature, and pressure data at approximately $3^{\circ} \mathrm{S}, 118^{\circ} \mathrm{E}$ in Makassar Strait (Fig. 1, inset; Gordon et al., 1998). The moorings were placed in the Labani Channel, a $45 \mathrm{~km}$ wide, $2 \mathrm{~km}$ deep constriction of the Makassar Strait. The MAK-1 mooring measured temperature and pressure at 12 points between 110 and $1500 \mathrm{dbar}$ (with sampling rates between $2 \mathrm{~min} / \mathrm{sample}$ and $20 \mathrm{~min} / \mathrm{sample}$ ) and measured velocity at 5 points between 200 and $1500 \mathrm{dbar}$ (at $20 \mathrm{~min} / \mathrm{sample}$ ). The MAK-2 mooring measured velocity and temperature at four levels between 200 and 750 dbar from December 1996 to February 1998. Gordon et al. (1998) report high correlations between MAK-1 and MAK-2 current records, with nearly identical transports calculated using both mooring time series or either mooring time series used independently for the full width of the channel. Because of its longer record and greater temperature data density, only MAK1 is employed in this study and is assumed to accurately describe the entire width of the Labani Channel.

Due to strong diurnal and semidiurnal tides as well as strong along-channel currents, the Makassar moorings experienced considerable deviation from the nominal vertical position, an occurrence we will call "blow-over" motion. The top-most temperature recorder sampled between its nominal depth of 110 dbar (at zero wire angle) and a maximum depth of $324 \mathrm{dbar}$, but stayed within the $110-210 \mathrm{dbar}$ range for $76 \%$ of the record; the mean recording pressure was 182 dbar. The topmost current meter sampled at a nominal depth of $200 \mathrm{dbar}$ (zero wire angle), recorded within 200$300 \mathrm{dbar}$ for $88 \%$ of the record, and achieved a maximum recording depth of $404 \mathrm{dbar}$; the mean recording pressure was $248 \mathrm{dbar}$. The remaining current meters on the MAK-1 mooring either were not fitted with pressure sensors or else had pressure sensors that failed during deployment. Recording pressures for these instruments are inferred by adding their nominal distance from the 200 dbar instrument. An analysis of mooring design that evaluates the effect of floatation and instrumentation on mooring blow-over shows that MAK-1 would have had nearly linear response to blow-over. The Aanderaa current meter packages employed a Savonious-type rotor to reduce the inertial response of the instrument to changes in current. The system is gimbal-mounted to be selfrighting up to wire angles of $18^{\circ}$, eliminating errors from instrument tilt (D. Pillsbury and B. Huber, personal communication, 2001). An analysis of the instrument pressure records indicates that wire angles for the $200 \mathrm{dbar}$ instrument may have exceeded $18^{\circ}$ for roughly $10 \%$ of the record. Thus, current speeds will have been underestimated for perhaps approximately $10 \%$ of the $200 \mathrm{dbar}$ record.

The Arlindo Makassar Strait measurements suggest a complex vertical profile of transport. The data indicate frequent occurrence of maximum southward speeds within the mid to lower thermocline (Gordon and Susanto, 1999; Gordon et al., 1999). The subsurface maximum occurs during times of large transport, from April to September 1997 and again in April 1998 to the end of the record in June 1998. An upward-looking ADCP at $150 \mathrm{~m}$ on MAK-2 provided a record of surface layer flow, but only from 1 December 1996 to 1 March 1997. The ADCP data show net northward transport in the surface layer, from 10 to $150 \mathrm{~m}$ (Gordon et al., 1999). Other studies also find northward surface flow during boreal winter: Mariano et al. (1995) surface current analysis, based on ship drift data from 1900 to 1991, shows 
weak Makassar flow to the north in the December average (their Fig. 3a), no Makassar surface flow during the winter (their Fig. 5c) and strong flow to the south in the summer (their Fig. 7c). Masumoto and Yamagata (1996), using the GFDL model forced by Hellerman and Rosenstein winds, show northward surface flow within Makassar Strait during the winter months. The $1 / 6^{\circ}$ resolution POP model displays a surface (upper $100 \mathrm{~m}$ ) flow towards the north in Makassar Strait during the winter, and towards the south in the summer months (Gordon and McClean, 1999).

Most vertical movement in the mooring line was due to strong diurnal and semi-diurnal tides, a fortuitous occurrence as it provides daily vertical profiling of temperature and current. In an attempt to take advantage of the constant vertical profiling introduced by mooring blow-over, temperature and current grids are constructed for this analysis from the top-most to lowest instrument using $10 \mathrm{dbar}$ increments and resampled to hourly temporal spacing after processing with a 2-day Lancos-type low-pass filter. These gridded fields are then used to compute volume transport, transport-weighted potential temperature and heat transport. Due to the gap in sampling above the highest mooring instrument, different interpolation schemes are employed to construct reasonable approximations of temperature and velocity profiles, described below. Speeds between $1500 \mathrm{dbar}$ and the seafloor (2137 $\mathrm{m}$ for MAK-1; Gordon and Susanto, 1999) are set equal to those measured by the $1500 \mathrm{dbar}$ current meter.

\subsection{Velocity interpolation (Makassar mooring data)}

Four profiles were constructed to constrain reasonable maximum and minimum currents between the surface and the top-most current meter. This method and rationale has been described previously in Gordon and Susanto (1999) and Gordon et al. (1999). The profiles are constructed as follows:

Profile A: Currents above the 200 dbar instrument linearly increase throughout the column to the surface. A linear least-squares fit was made between the four upper current meters (200, 250, 350 and $750 \mathrm{dbar})$ and used as an extrapolant to the surface. Profile A yields maximum southward transport.

Profile B: Currents at all levels from the surface to the $200 \mathrm{~m}$ instrument are equal to the value measured by the $200 \mathrm{~m}$ instrument.

Profile C: Currents linearly decrease to zero from the $200 \mathrm{~m}$ instrument to the surface. Profile $\mathrm{C}$ yields minimum southward transport. Profile D: Profile A is used during boreal summer (June-August), Profile B is used during the equinox seasons (March-May) and (September-November) and Profile $\mathrm{C}$ is used during boreal winter (December-February). This seasonal mixture is based on observations and models of the Makassar surface flow as described in the introduction.

Although Profiles $\mathrm{A}$ and $\mathrm{C}$ are considered "reasonable" maximum and minimum estimates for the upper level current structure, there is a possibility that the actual flow regime falls outside Profile A or C. Weak northward surface flows confined to the boreal winter have been observed (Fig. 3c of Mariano et al., 1995; the ADCP data shown by Gordon et al., 1999) and seen in models (e.g. Gordon and McClean, 1999), indicating that our Profile $\mathrm{C}$ may overestimate the southward transport of the surface layer during boreal winter. Additionally, the consideration of normal mode fits to the Makassar data (Wajsowicz, personal communication) suggests that Profile A may underestimate the southward flow in the surface layer.

Volume transports are calculated by multiplying the along-channel velocity component at each grid point by its corresponding channel-width area element at that depth, then summing over the column depth. As noted in Section 2.1, the MAK1 and MAK-2 records correlate to 0.94 (Gordon et al., 1998), so using MAK-1 records for the channel width is considered reasonable. The average depth-integrated (summed from bottom to the surface) volume transport for each profile is shown in Fig. 2. It is clear that all of the volume transport is contained in the upper $700 \mathrm{dbar}$ of the $2137 \mathrm{~m}$ water column (upper $1900 \mathrm{~m}$ shown). This has been shown in Fig. 5 of Gordon et al. (1998), 


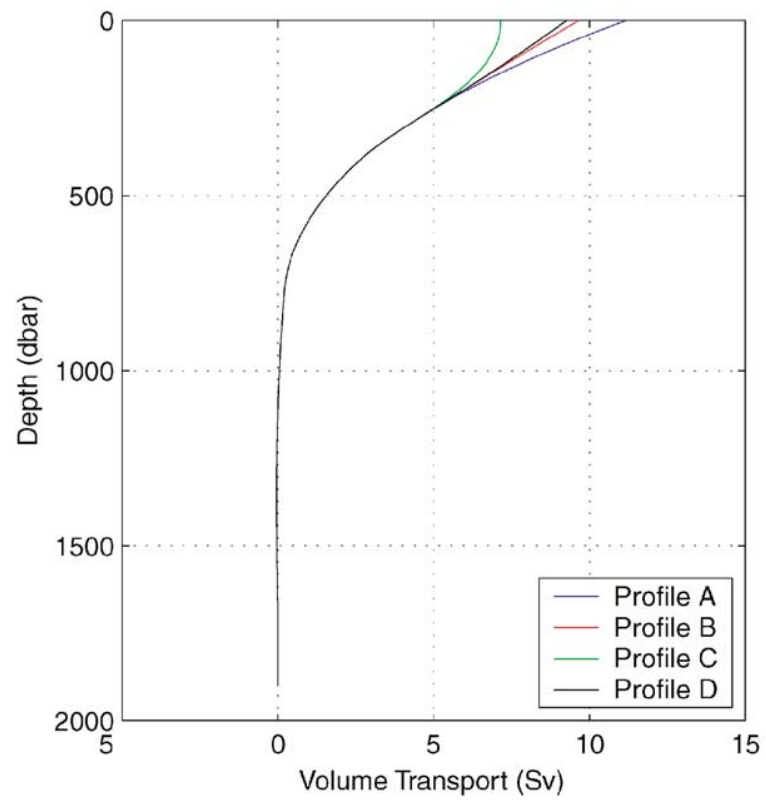

Fig. 2. Makassar volume transport from MAK-1, integrated from the seafloor (approx. $1900 \mathrm{~m}$ ) to the surface (cumulative upwards). Four interpolation profiles are shown (see text). $\left(1 \mathrm{~Sv}=10^{6} \mathrm{~m}^{3} \mathrm{~s}^{-1}\right)$.

noting the presence of a sill at $650 \mathrm{~m}$ blocking the southern Makassar Strait (Gordon et al., 1994). The time series of volume transport (upper 700 dbar only) for four interpolation profiles are given in the upper panels of Fig. 3a-d. The December 1996-July 1998 mean volume transport for the four profiles are given in column 1 of Table 1. From here forward, calculations will be made using only the upper $700 \mathrm{dbar}$ of the Makassar water column.

Errors in the velocity data stem from the current-meter instrument package exceeding maximum instrument tilt for approximately $10 \%$ of the record and from lack of knowledge of upper level flows. While the mooring blow-over was fortuitous in providing daily profiling of the vertical water column (Gordon et al., 1999; Ffield et al., 2000), the blow-over introduces added uncertainty in upper level flows by increasing the depth interval from the surface without measurements. The use of interpolation profiles in attempting to constrain reasonable maximum and minimum upper column flows (i.e. Profiles A and C) adds or subtracts about $2 \mathrm{~Sv}(20 \%)$ from the Profile B and D average of $9.2 \mathrm{~Sv}$. These profiles are also assumed to constrain the error introduced by current meters tilted beyond $18^{\circ}$ from vertical. In horizontal space, the MAK-1 mooring measurements within any given vertical interval are assumed to be representative for the channel within that vertical interval.

\subsection{Temperature interpolation (Makassar mooring data)}

Twelve instruments recorded temperature between 110 and $1500 \mathrm{dbar}$ with sampling rates between 2 and $20 \mathrm{~min} / \mathrm{sample}$. All temperature records were first filtered with a 2-day Lancos-type low-pass filter and then resampled to hourly temporal spacing. Temperatures between the uppermost instrument and the surface were linearly interpolated using weekly NCEP OI surface temperatures, also resampled to hourly spacing. CTD profiles from the Arlindo cruises (1994-1996) show fairly linear temperature decrease from the surface to approximately $250 \mathrm{~m}$, indicating that linear interpolation is justified. Analysis of Makassar Strait CTD casts taken from both monsoon seasons indicates that linear interpolation will underestimate the upper $300 \mathrm{dbar}$ average temperature by an average of $0.6^{\circ} \mathrm{C}$ and a maximum of $1.3^{\circ} \mathrm{C}$, with all differences greater than one standard deviation occurring during winter monsoon. Temperatures below the temperature recorder at $750 \mathrm{dbar}$ are ignored as we use only the upper $700 \mathrm{dbar}$ for all calculations employing temperature in this study (see below).

\section{Makassar heat transport calculation}

A calculation of the heat transport of the Makassar Strait follows the discussion of Warren (1999). Along-channel speed grids (for each interpolation profile) and a potential temperature grid are constructed from the ocean surface to $700 \mathrm{dbar}$ using linear interpolation between instruments as described in Section 2. At each pressure interval, the potential temperature grid, volume transport 

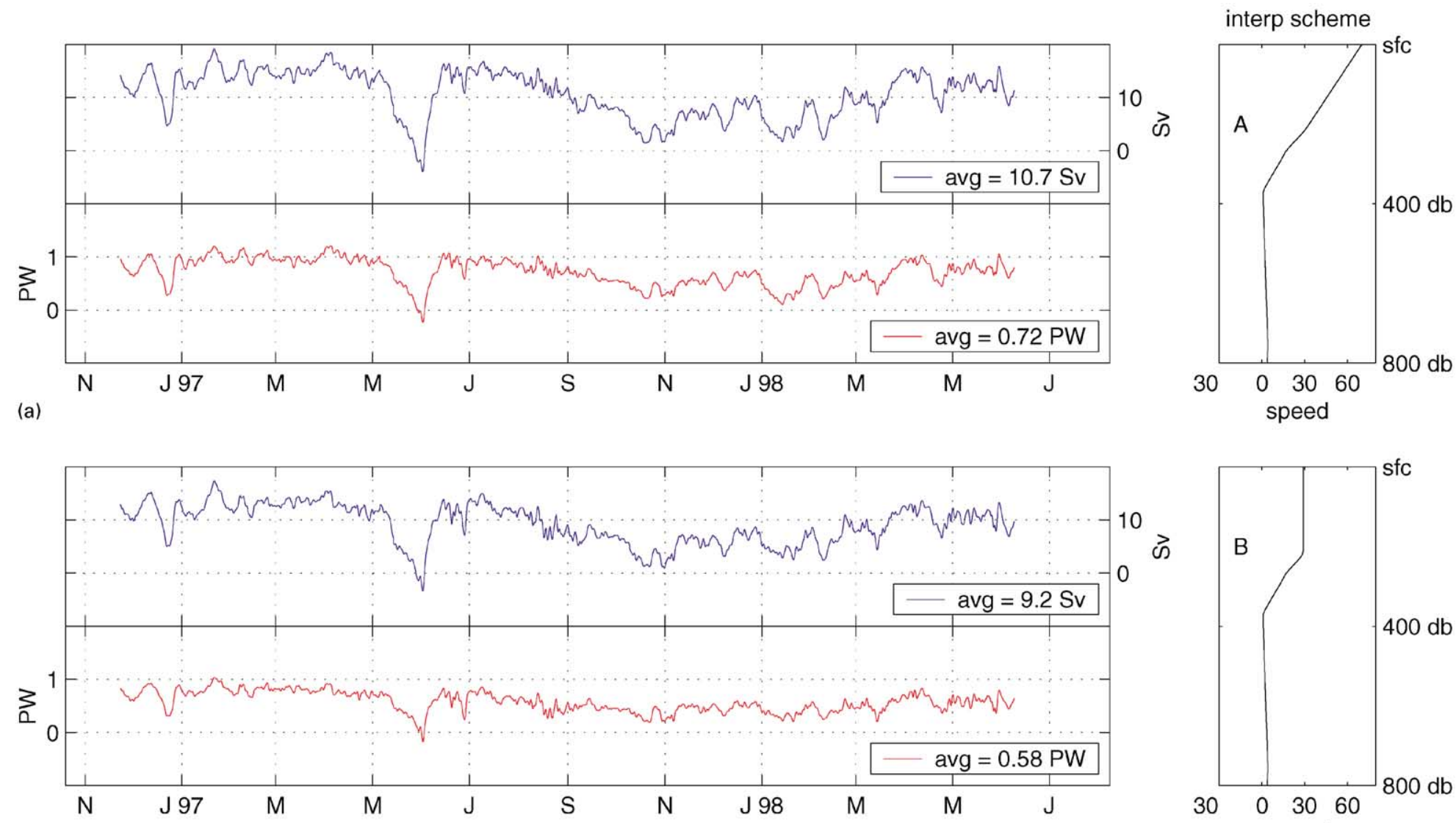

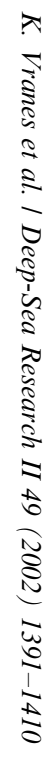

(b)

Fig. 3. (a-d) Time series of volume transport (blue) and heat transport (red) for four interpolation profiles for upper 700 dbar of Makassar water column. 

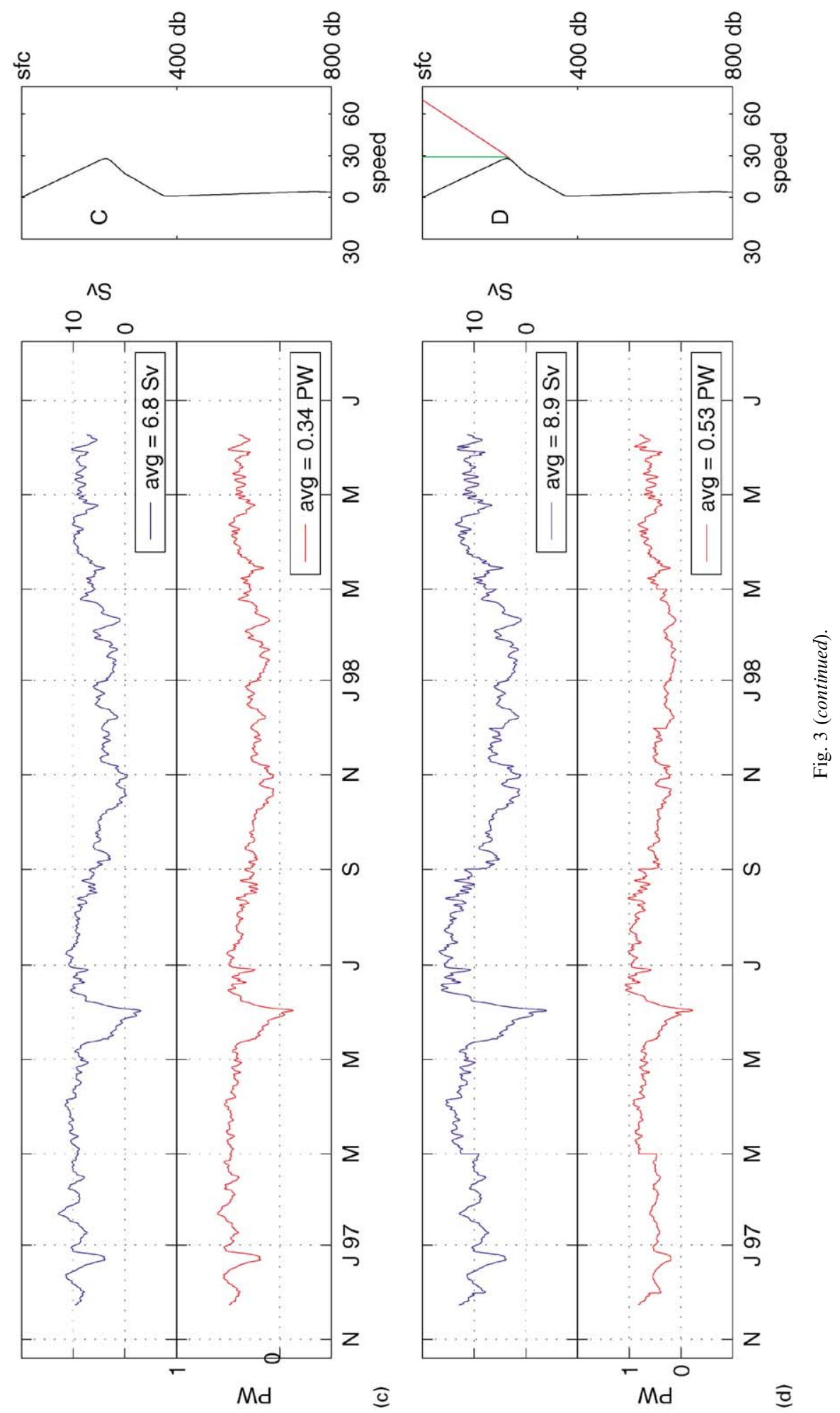
Table 1

Values of volume and heat transport (referenced to $3.4^{\circ} \mathrm{C}$ ) calculated for the four upper layer interpolation profiles for December 1996July 1998 record. Transport-weighted temperatures and Indian Ocean heat flux divergences are also shown

\begin{tabular}{|c|c|c|c|c|c|}
\hline & $\begin{array}{l}\text { Makassar } \\
\text { volume transport } \\
\text { (upper } 700 \mathrm{~m} \text { ) } \\
(\mathrm{Sv})\end{array}$ & $\begin{array}{l}\text { Makassar transport- } \\
\text { weighted potential } \\
\text { temperature }\left({ }^{\circ} \mathrm{C}\right)\end{array}$ & $\begin{array}{l}\text { Makassar heat } \\
\text { transport (upper } \\
700 \mathrm{~m} \text { ) ref. to } \\
3.4^{\circ} \mathrm{C}(\mathrm{PW})\end{array}$ & $\begin{array}{l}\text { Makassar- } \\
\text { Agulhas heat flux } \\
\text { divergence along } \\
\sigma_{\theta} \text { surfaces (PW) }\end{array}$ & $\begin{array}{l}\text { Makassar- } \\
\text { Agulhas heat flux } \\
\text { divergence along } \\
p \text { surfaces (PW) }\end{array}$ \\
\hline Profile A & 10.8 & 16.3 & 0.57 & -0.02 & -0.01 \\
\hline Profile B & 9.3 & 15.2 & 0.45 & -0.03 & -0.03 \\
\hline Profile C & 6.9 & 12.1 & 0.24 & -0.04 & -0.07 \\
\hline Profile D & 8.9 & 14.7 & 0.41 & -0.03 & -0.04 \\
\hline
\end{tabular}

grid and corresponding in-situ density are multiplied together and the product by the specific heat of sea water (taken as constant) following:

$E=c_{p} \int_{0}^{\mathrm{sfc}} \rho v\left(\theta-\theta_{\mathrm{r}}\right) \mathrm{d} \sigma$

where $\sigma$ is the corresponding area element, $\theta_{\mathrm{r}}$ is the reference temperature and $c_{p}=4 \times 10^{3} \mathrm{~J} \mathrm{~K}^{-1} \mathrm{~kg}^{-1}$. These grids are then summed vertically, producing a time series of heat transport (lower panels, Fig. 3a-d).

For the upper 700 dbar, the December 1996July 1998 heat transport range is $0.57 \mathrm{PW}$ for Profile A to $0.24 \mathrm{PW}$ for Profile C (referenced to $3.4^{\circ} \mathrm{C}$, as discussed below). The mean of Profile B and Profile D heat transports is $0.43 \mathrm{PW}$. The average volume transport, heat transport and transport-weighted average temperature for each profile are shown in Table 1, while heat transports calculated for each profile using various reference temperatures are shown in Table 2. In Table 2 we also show the sea-air heat forcing $\left(Q_{\mathrm{f}}\right)$ if the ITF were to cool to various reference temperatures within the Indian Ocean by exchanging heat with the atmosphere. This assumes the area of the Indian Ocean north of $30^{\circ} \mathrm{S}$ is $3.5 \times 10^{13} \mathrm{~m}^{2}$.

The ENSO influence on the heat transport record is evident. For Profile B, the mean heat transport for 1 December 1996-31 January 1997 (moderate La Niña) is $0.76 \mathrm{PW}$ with $12.1 \mathrm{~Sv}$ volume transport; the mean heat transport for 1 December 1997-31 January 1998 (strong El Niño) is $0.42 \mathrm{PW}$ with $5.6 \mathrm{~Sv}$ volume transport.
Different studies use various values as a 'reference temperature'. The choice of reference temperature is somewhat arbitrary and depends largely on where the authors decide to close their sections for zero net volume transport (Ffield et al., 2000). The use of a reference temperature is intended to close the section at a convenient place where all return flow must cross, thus creating a closed system. In this case, appropriate closure sections might be a meridional section between Australia and Antarctica or a zonal section between Australia and South America. Most authors use reference temperatures between $0^{\circ} \mathrm{C}$ and $4^{\circ} \mathrm{C}$ (Schneider and Barnett, 1997; Schiller et al., 1998; Gordon and McClean, 1999), ostensibly characteristic of the average temperature across one of the aforementioned closure lines (see Table 3). In the text of this paper we follow Schneider and Barnett (1997) in citing results using $3.4^{\circ} \mathrm{C}$ as a reference temperature, which is the spatially averaged temperature between Australia and Antarctica. We provide the results for all profiles using reference temperatures between $0^{\circ} \mathrm{C}$ and $4{ }^{\circ} \mathrm{C}$ in Table 2. Calculations made with reference temperatures from $0^{\circ} \mathrm{C}$ to $4^{\circ} \mathrm{C}$ for Profile $\mathrm{D}$ change our heat transport results from $0.39 \mathrm{PW}$ $\left(4{ }^{\circ} \mathrm{C}\right.$ reference temperature; Table 2$)$ to $0.53 \mathrm{PW}$ $\left(0^{\circ} \mathrm{C}\right.$ reference temperature; Table 2$)$.

A 12-month running average of Profile D volume transport, transport-weighted potential temperature and heat transport, overlain by the NINO3 index, from June 1997 to January 1998 is presented in Fig. 4. Transport-weighted potential temperature gives a practical measure of the 
Table 2

Comparison of Makassar Strait heat transport (December 1996-July 1998) using various reference temperatures. In parentheses, potential Indian Ocean air-sea heat forcing introduced by Indonesian Throughflow heat transport assuming Indian Ocean basin area north of $30^{\circ} \mathrm{S}$ of $3.5 \times 10^{13} \mathrm{~m}^{-2}$, assuming all ITF heat escapes through the surface of the Indian Ocean

\begin{tabular}{|c|c|c|c|c|c|}
\hline & $0^{\circ} \mathrm{C}$ & $2.8^{\circ} \mathrm{C}$ & $3.4^{\circ} \mathrm{C}$ & $3.72^{\circ} \mathrm{C}$ & $4^{\circ} \mathrm{C}$ \\
\hline Profile A & $\begin{array}{l}0.72 \mathrm{PW} \\
\left(20.5 \mathrm{~W} \mathrm{~m}^{-2}\right)\end{array}$ & $\begin{array}{l}0.59 \mathrm{PW} \\
\left(16.9 \mathrm{~W} \mathrm{~m}^{-2}\right)\end{array}$ & $\begin{array}{l}0.57 \mathrm{PW} \\
\left(16.2 \mathrm{~W} \mathrm{~m}^{-2}\right)\end{array}$ & $\begin{array}{l}0.55 \mathrm{PW} \\
\left(15.7 \mathrm{~W} \mathrm{~m}^{-2}\right)\end{array}$ & $\begin{array}{l}0.54 \mathrm{PW} \\
\left(15.4 \mathrm{~W} \mathrm{~m}^{-2}\right)\end{array}$ \\
\hline Profile B & $\begin{array}{l}0.58 \mathrm{PW} \\
\left(16.5 \mathrm{~W} \mathrm{~m}^{-2}\right)\end{array}$ & $\begin{array}{l}0.47 \mathrm{PW} \\
\left(13.4 \mathrm{~W} \mathrm{~m}^{-2}\right)\end{array}$ & $\begin{array}{l}0.45 \mathrm{PW} \\
\left(12.9 \mathrm{~W} \mathrm{~m}^{-2}\right)\end{array}$ & $\begin{array}{l}0.43 \mathrm{PW} \\
\left(12.3 \mathrm{~W} \mathrm{~m}^{-2}\right)\end{array}$ & $\begin{array}{l}0.42 \mathrm{PW} \\
\left(12.0 \mathrm{~W} \mathrm{~m}^{-2}\right)\end{array}$ \\
\hline Profile C & $\begin{array}{l}0.34 \mathrm{PW} \\
\left(9.7 \mathrm{~W} \mathrm{~m}^{-2}\right)\end{array}$ & $\begin{array}{l}0.26 \mathrm{PW} \\
\left(7.4 \mathrm{~W} \mathrm{~m}^{-2}\right)\end{array}$ & $\begin{array}{l}0.24 \mathrm{PW}^{-2} \\
\left(6.9 \mathrm{~W} \mathrm{~m}^{-2}\right)\end{array}$ & $\begin{array}{l}0.24 \mathrm{PW} \\
\left(6.9 \mathrm{~W} \mathrm{~m}^{-2}\right)\end{array}$ & $\begin{array}{l}0.23 \mathrm{PW} \\
\left(6.6 \mathrm{~W} \mathrm{~m}^{-2}\right)\end{array}$ \\
\hline Profile D & $\begin{array}{l}0.53 \mathrm{PW} \\
\left(15.1 \mathrm{~W} \mathrm{~m}^{-2}\right)\end{array}$ & $\begin{array}{l}0.43 \mathrm{PW} \\
\left(12.3 \mathrm{~W} \mathrm{~m}^{-2}\right)\end{array}$ & $\begin{array}{l}0.41 \mathrm{PW} \\
\left(11.7 \mathrm{~W} \mathrm{~m}^{-2}\right)\end{array}$ & $\begin{array}{l}0.40 \mathrm{PW} \\
\left(11.4 \mathrm{~W} \mathrm{~m}^{-2}\right)\end{array}$ & $\begin{array}{l}0.39 \mathrm{PW} \\
\left(11.1 \mathrm{~W} \mathrm{~m}^{-2}\right)\end{array}$ \\
\hline
\end{tabular}

Table 3

Comparison of ITF model calculations of heat transport (heat flux for Hirst/Godfrey; HF stands for 'heat flux,' HT stands for 'heat transport'). Mooring observations given at bottom. The right column is an assessment of whether the bottom topography used accurately reproduces the complexity of that found in the Indonesian seas. Many of the important straits in the region are less than $1^{\circ}$ wide

\begin{tabular}{|c|c|c|c|c|c|c|c|}
\hline & $\begin{array}{l}\text { Vol. } \\
\text { transport } \\
(\mathrm{Sv})\end{array}$ & $\begin{array}{l}\text { Ref. } \\
\text { temp } \\
\left({ }^{\circ} \mathrm{C}\right)\end{array}$ & $\begin{array}{l}\text { Heat flux or } \\
\text { transport } \\
(\mathrm{PW})\end{array}$ & Model used & Resolution & Forced by & $\begin{array}{l}\text { Realistic } \\
\text { topography? }\end{array}$ \\
\hline $\begin{array}{l}\text { Hirst and Godfrey } \\
\text { (1993) }\end{array}$ & 17 & - & $0.62(\mathrm{HF})$ & $\begin{array}{l}\text { Bryan-Cox } \\
\text { OGCM }\end{array}$ & $\begin{array}{l}1.6^{\circ} \times 2.8^{\circ} \\
12 \text { levels }\end{array}$ & $\begin{array}{l}\text { Hellerman } \\
\text { and } \\
\text { Rosenstein }\end{array}$ & No \\
\hline $\begin{array}{l}\text { Schneider and } \\
\text { Barnett (1997) }\end{array}$ & 13.8 & 3.4 & $0.9(\mathrm{HT})$ & ECHO & $\begin{array}{l}2.8^{\circ} \times 2.8^{\circ} \\
19 \text { levels }\end{array}$ & coupled & No \\
\hline Schiller et al. (1998) & 16 & 3.72 & $1.15(\mathrm{HT})$ & $\begin{array}{l}\text { GFDL } \\
\text { MOM2 }\end{array}$ & $\begin{array}{l}2^{\circ} \times 0.5^{\circ} \text { (tropics) } \\
25 \text { levels }\end{array}$ & FSU & No \\
\hline $\begin{array}{l}\text { Gordon and } \\
\text { McClean (1999) }\end{array}$ & 12 & 2.8 & $0.66(\mathrm{HT})$ & LANL POP & $1 / 6^{\circ}-20$ levels & ECMWF & ETOP05 \\
\hline $\begin{array}{l}\text { Lebedev and } \\
\text { Yaremchuk (2000) }\end{array}$ & 11.5 & 2.8 & $0.83(\mathrm{HT})$ & $\begin{array}{l}\text { Demin / } \\
\text { Ibraev (89) } \\
\text { OGCM }\end{array}$ & $\begin{array}{l}1 / 6^{\circ}-32 \text { levels (in } \\
\text { Indonesian Seas) }\end{array}$ & $\begin{array}{l}\text { Hellerman } \\
\text { and } \\
\text { Rosenstein }\end{array}$ & ETOP05 \\
\hline \multirow{2}{*}{$\begin{array}{l}\text { December } 1996-\text { July } \\
1998 \text { observations }\end{array}$} & 9.4 & 3.4 & 0.45 & Profile B & - & - & - \\
\hline & 8.9 & 3.4 & 0.41 & Profile D & - & - & - \\
\hline
\end{tabular}

temperature of water actually being transported through the Makassar Strait. A relationship of volume and heat transport to NINO3, as noted by Gordon et al. (1999) and Ffield et al. (2000), is suggested, although the record is much too short to calculate correlations with confidence. (How- ever, Ffield et al., 2000, show a clear relationship between ENSO and Makassar thermocline behavior using a 15-year record of $100 \mathrm{~m}$ XBT temperatures.) The amplitude of the transportweighted potential temperature is less than $\pm 0.25^{\circ} \mathrm{C}$. It is noted that the transport-weighted 


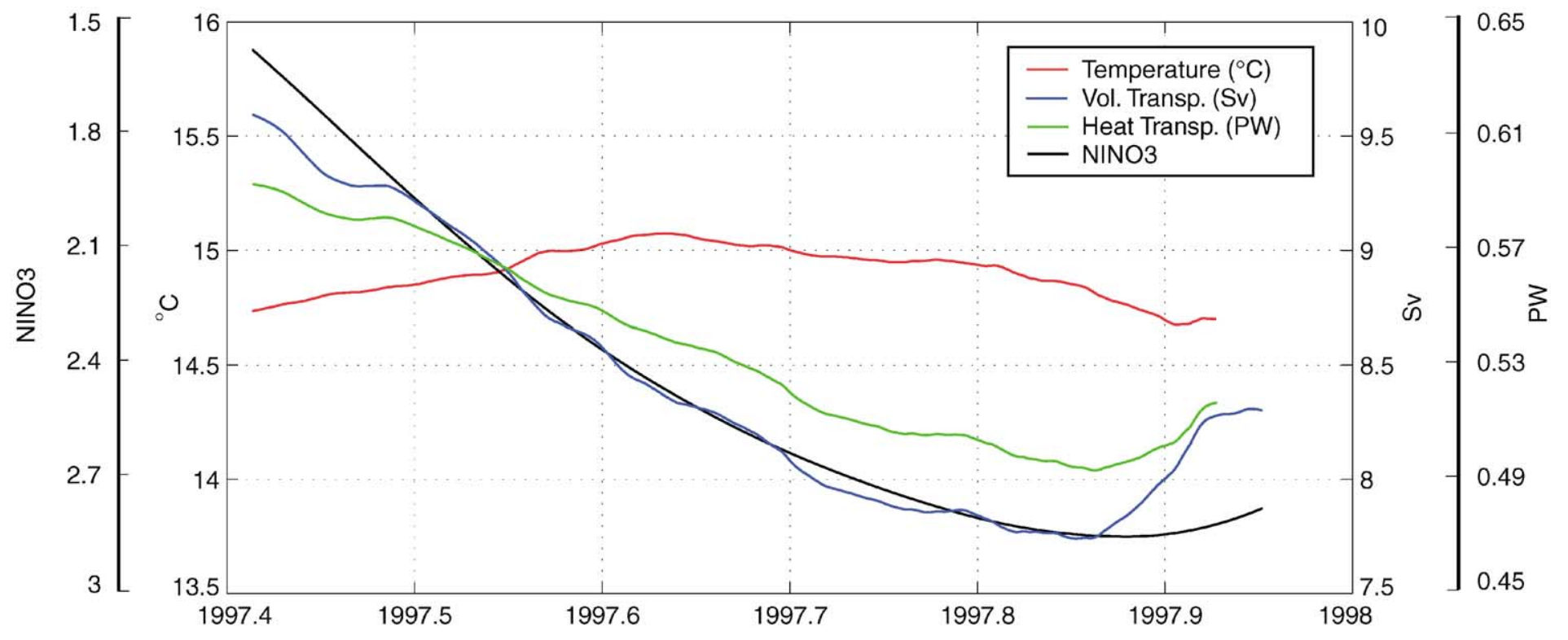

Fig. 4. 12-month running mean of Profile D volume transport, energy transport and transport-weighted potential temperature, overlain by inverted NINO3 index 
potential temperature is not always in phase with volume and heat transport. For the first three months of the averaging window, the transportweighted potential temperature displays a slope opposite to that of the volume transport; near June 1997, when the transport falls below $8.3 \mathrm{~Sv}$, the slope changes to follow that of transport. This behavior is a consequence of the changing velocity profile with transport changes. The center of maximum current speed shifts to greater depth (cooler water) during periods of high volume transport (Gordon et al., 1999). Thus during periods of high volume transport, the transportweighted temperature will be influenced to a greater degree by cooler water. In late 1997 the transport increases but the transport-weighted temperature does not change its slope, until the transport attains $8.2 \mathrm{~Sv}$. Apparently there is a change in the relationship of the velocity profile to transport when the transport is near $8.25 \mathrm{~Sv}$. A topic for future study when longer time series might become available is to elucidate the dependence of the ITF velocity profile to ITF water mass recipe in response to ENSO.

\section{Comparison with other studies}

Heat transport calculated using the Arlindo moorings are compared to model studies of heat transport and/or heat flux in Table 3. There is not a standard method for quantifying heat transport in the Indonesian seas. For example, Hirst and Godfrey (1993) use the difference in surface heat flux between the Pacific and Indian Oceans to infer Indonesian seas heat flux. Schneider and Barnett (1997) use a modified form of the Hall and Bryden (1982) "direct method", calling their result the "advective heat flux", while Gordon and McClean (1999) explicitly use the direct method. Schiller et al. (1998) follow Hirst and Godfrey (1993) within the Indonesian seas, but also calculate the heat transport across a section from northwest Australia to south Java, following the Hall and Bryden (1982) method (A. Schiller, personal communication, 2000). Lebedev and Yaremchuk (2000) follow Gordon and McClean (1999) closely, using the same reference temperature $\left(2.8^{\circ} \mathrm{C}\right)$.
This inconsistency creates practical difficulty in synthesizing various estimates of the Indonesian Throughflow heat transport, making it difficult to quantify the differences between calculation methods. An obvious point of comparison is in reference temperature. How our heat transport results change with different reference temperatures is shown in Table 2. Only Hirst and Godfrey (1993) calculate surface heat flux differences without directly calculating heat transport through advection. We include that study as an oft-cited important early work in modeling the ITF, one upon which other studies cited here draw.

From a hydrographic section along $32^{\circ} \mathrm{S}$, Toole and Warren (1993) estimate an Indian Ocean net heat divergence of $0.98 \mathrm{PW}$, using an ITF volume transport of $6.7 \mathrm{~Sv}$, which introduces $0.69 \mathrm{PW}$ into the Indian Ocean solely from the ITF. However, the Makassar mooring data show that their assumption of $24^{\circ} \mathrm{C}$ transport-weighted potential temperature of the ITF is too much higher than our measured values of between $12.1^{\circ} \mathrm{C}$ and $16.3^{\circ} \mathrm{C}$. Robbins and Toole (1997) improve upon Toole and Warren (1993) by introducing a silica constraint not used in the original study, and find a Indonesian Throughflow of $5.3 \pm 3.5 \mathrm{~Sv}$ and net Indian Ocean heat divergence of $0.42 \pm 0.19 \mathrm{PW}$. However, they do not cite specific values for the ITF heat transport. Ganachaud et al. (2000) finds $1.36 \pm 0.15 \mathrm{PW}$ advected across the JADE89 (Fieux et al., 1994) section between Indonesia and NW Australia using a geostrophic inverse box model, although they point out that the ITF in this region displays large seasonal variability and hence their estimate may be strongly influenced by the use of a single hydrographic section.

\section{Divergence of ITF heat in the Indian Ocean}

The ITF waters must eventually exit the Indian Ocean across $30^{\circ} \mathrm{S}$, but at what temperature? Two non-mutually exclusive processes can affect the temperature of ITF water within the Indian Ocean: (1) Through sea-air heat exchange; (2) By mixing with other water parcels of different temperature that have been injected into the Indian Ocean across $30^{\circ} \mathrm{S}$. In the latter case the 


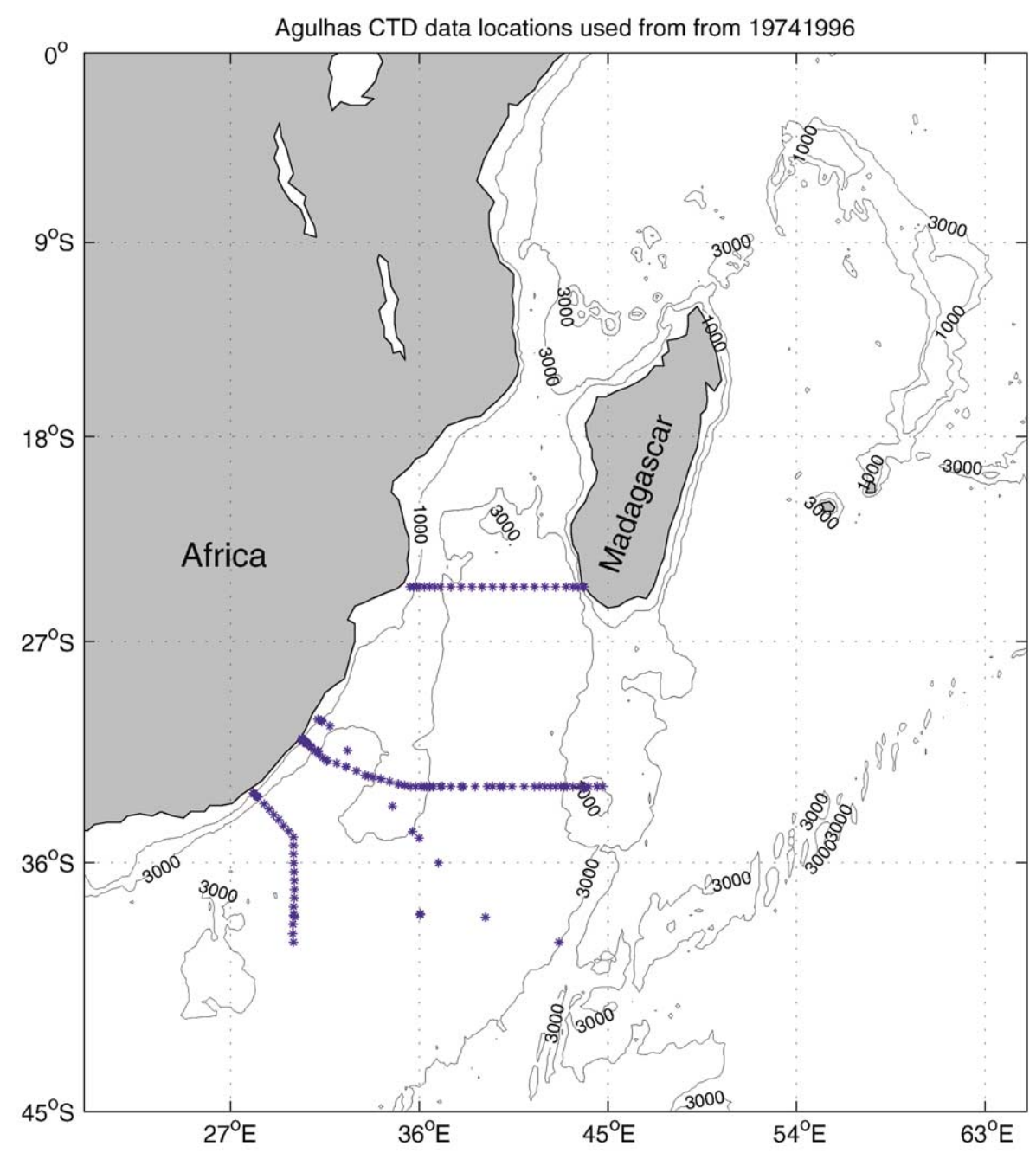

Fig. 5. Locations of Agulhas hydrographic stations (158 total) used to calculate Indian Ocean heat flux divergence due to Indonesian Throughflow. 1000 and $3000 \mathrm{~m}$ isobaths shown.

combined transport and blended temperature pass poleward across $30^{\circ} \mathrm{S}$. Only the former process is responsible for heat flux divergence of the ITF water, which is what we want to determine. As we do not know the relative contributions from each process, we assume all of the ITF temperature change before crossing $30^{\circ} \mathrm{S}$ is due to air-sea heat exchange. This approach yields maximum estimates of the ITF heat divergence. Even with this assumption, as shown below the ITF heat divergence is fairly small.
While previous studies have estimated Indian Ocean heat flux divergence (Macdonald, 1993; Toole and Warren, 1993; Macdonald and Wunsch, 1996; Garternicht and Schott, 1997; Robbins and Toole, 1997; Ganachaud and Wunsch, 2000; Ganachaud et al., 2000) all studies either use a nominal value for ITF volume transport (usually $10 \mathrm{~Sv}$ ) or use a value necessitated by inverse geostrophic solutions of hydrographic data. We wish to use direct velocity and temperature measurements from the Indonesian seas to 

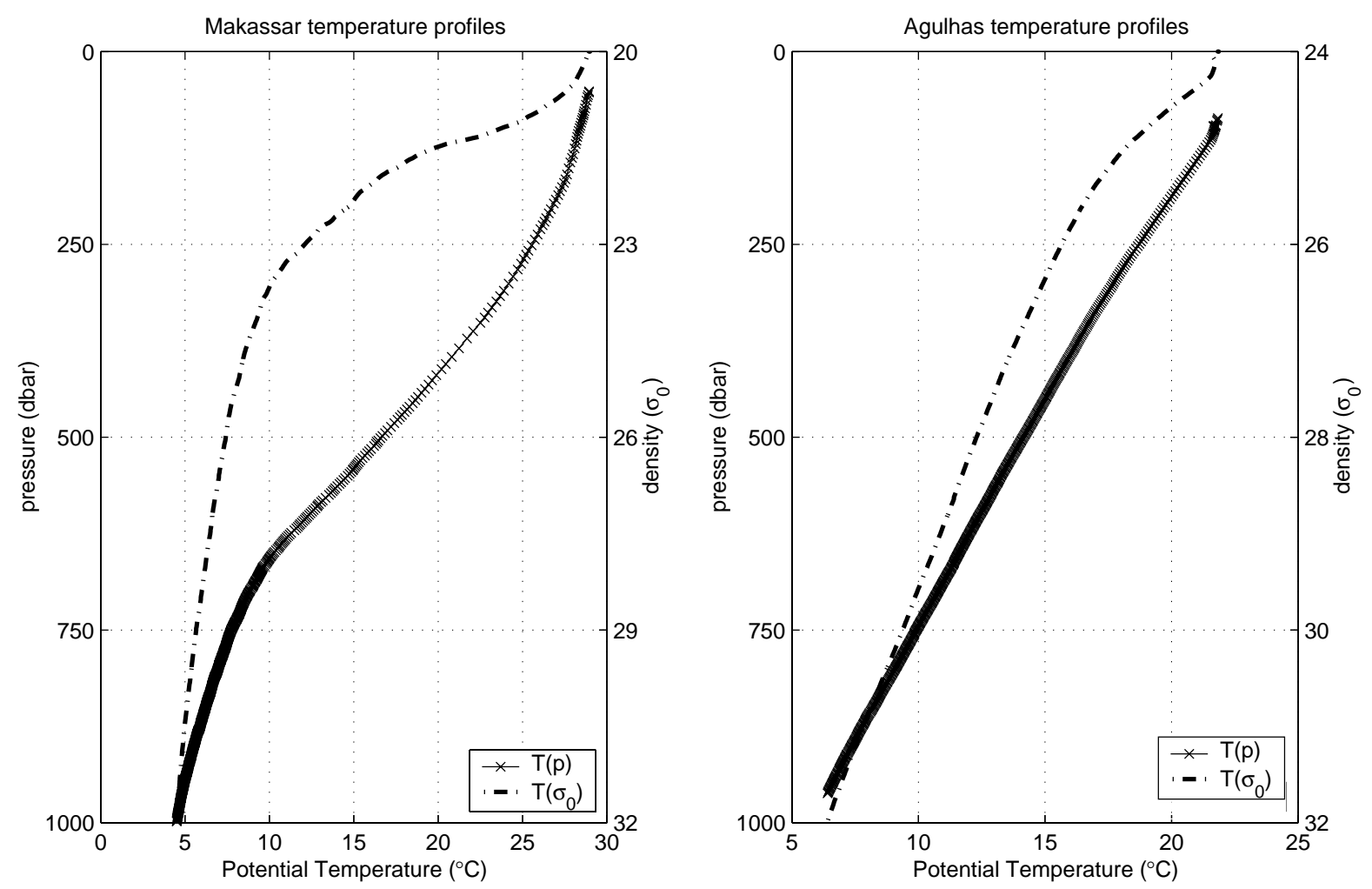

Fig. 6. Potential temperature vs. pressure (solid line) and potential temperature vs. potential density (dash-dotted line) relationships for Makassar Strait (a) and Agulhas Current region (b).

estimate the divergence of ITF heat within the Indian Ocean.

With the possible exception of the weak and seasonally dependent Leeuwin Current off western Australia (net volume transport close to zero, according to Godfrey and Ridgway (1985), but perhaps a net poleward transporter of heat, according to Godfrey (1996)), the only southward flow crossing $30^{\circ} \mathrm{S}$ in the Indian Ocean basin at surface and thermocline depths is the Agulhas Current (Toole and Warren, 1993). We rule out as significant the poleward eddy heat flux across the quiescent central latitudes of the subtropical gyre relative to that of the Agulhas western boundary advective heat flux. Stammer (1998) has shown that the transport of heat by eddies is less than $0.05 \mathrm{PW}$ across $30^{\circ} \mathrm{S}$ in the Indian Ocean (his Figs. 7 and 8). It is furthermore unreasonable to expect the Indonesian Throughflow to be cooled to deep-water temperatures. We therefore expect that all flow entering the Indian Ocean from the ITF must exit via the Agulhas Current. Whether or not it does this immediately or recirculates within the Indian Ocean before eventually exiting is still unclear (Gordon et al., 1997). Two extremes are considered that serve to constrain reasonable behaviors of ITF water once in the Indian Ocean. However, it is noted that for the two extreme but possible scenarios presented below (ITF crosses $30^{\circ} \mathrm{S}$ with the warmest SST at $30^{\circ} \mathrm{S}$ or with waters not warmer than the coolest winter SST found north of $30^{\circ} \mathrm{S}$ ) the ITF waters may be transferred by eddies as well as the Agulhas Current.

While the total Agulhas Current volume flow has been given variously between 75-100 Sv (e.g. Gordon et al., 1987; Read and Pollard, 1993; Toole and Warren, 1993; Schmitz, 1995; Beal and Bryden, 1999), we are concerned solely with the 


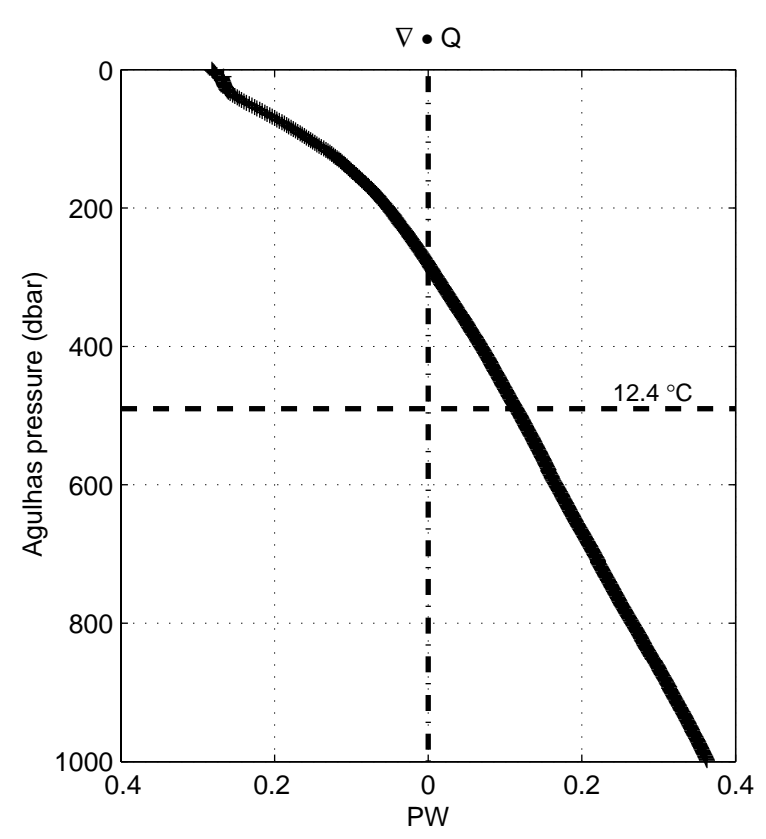

Fig. 7. Heat flux divergence north of $30^{\circ} \mathrm{S}$ resulting from the Indonesian Throughflow for transport-weighted potential temperature of $15.2^{\circ} \mathrm{C}$. Plot indicates total heat divergence if all Makassar water were to exit the Indian Ocean at one Agulhas temperature. If all Makassar water warmer than the coldest austral winter SST in the Indian Ocean were cooled to that temperature, the Makassar transport-weighted temperature would be reduced to $12.4^{\circ} \mathrm{C}$.

contribution from the ITF $(\sim 10 \mathrm{~Sv})$. In this sense, we are making an estimate of the component of the Indian Ocean heat flux divergence arising from the input of the Indonesian Throughflow. We do not know the history of the ITF water within the Indian Ocean to be able to fix its temperature crossing $30^{\circ} \mathrm{S}$, but we can offer various scenarios that provide bounds and reasonable estimates for the ITF heat divergence. Hydrographic data from the Agulhas Current region (Figs. 5 and 6b) is used to determine average potential temperature both within 10-dbar increments and within potential density surfaces of $0.1 \sigma_{\theta}$. All WOCE and NODC CTD data collected between 1974 and 1996 in the vicinity of the Agulhas Current region are used: temperature and salinity data were gathered from 158 hydrographic stations spanning $23-40^{\circ} \mathrm{S}$ and $27-45^{\circ} \mathrm{E}$ (Fig. 5). The 158 stations were averaged to give a mean temperature profile of the Agulhas Current (Fig. 6b). Salinity is used only to calculate a vertical potential density profile of the Agulhas Current region.

The Makassar Strait transport-weighted potential temperature for the upper $700 \mathrm{dbar}$ (Profile B) is $15.2^{\circ} \mathrm{C}$ (Table 1). The average surface temperature from the 158 Agulhas Current stations is $22.0^{\circ} \mathrm{C}$ and the average Agulhas surface density is $1024.6 \mathrm{~kg} \mathrm{~m}^{-3}$. This gives a heat flux divergence $\nabla Q=-0.28 \mathrm{PW}$ if all Makassar water exits the Indian Ocean at the surface of the Agulhas (Fig. 7). Negative heat flux divergence indicates that the ITF has gained heat within the Indian Ocean before exiting within the Agulhas Current. The ITF cannot warm greater than the Agulhas SST so $-0.28 \mathrm{PW}$ is the maximum negative heat flux divergence north of $30^{\circ} \mathrm{S}$.

A reasonable maximum positive heat flux divergence would be achieved if all Makassar water were to be cooled to the coldest Southern Hemisphere winter SST in the Indian Ocean. The coldest winter Indian Ocean SST north of $30^{\circ} \mathrm{S}$ is roughly $16^{\circ} \mathrm{C}$ (Conkright et al., 1998); if all Makassar water warmer than $16^{\circ} \mathrm{C}$ were cooled to $16^{\circ} \mathrm{C}$, the transport-weighted potential temperature of ITF (for Profile B) would be reduced to $12.4^{\circ} \mathrm{C}$. This is the coldest level we can reasonably expect Makassar water to exit the Agulhas. Thus, if Makassar water at $15.2^{\circ} \mathrm{C}$ were to be cooled and exit the Agulhas at $12.4^{\circ} \mathrm{C}$ $\left(1028.8 \mathrm{~kg} \mathrm{~m}^{-3}\right)$, the heat flux divergence would be $\nabla Q=0.11 \mathrm{PW}$. Fig. 7 shows a range of heat flux divergences for given exit temperatures at the Agulhas based on Makassar transport-weighted temperature of $15.2^{\circ} \mathrm{C}$.

It is unlikely that all ITF water exits the Indian Ocean at the Agulhas SST or at a temperature colder than $12.4^{\circ} \mathrm{C}$. We now consider more plausible intermediate scenarios, with the ITF waters distributed within specific depth intervals of the Agulhas Current: (1) The ITF exits the Agulhas within the same depth (pressure) range of the Makassar Strait transport; (2) The ITF exits the Agulhas within the same potential density interval of the Makassar Strait transport. In the latter case, the Makassar water loses buoyancy as 

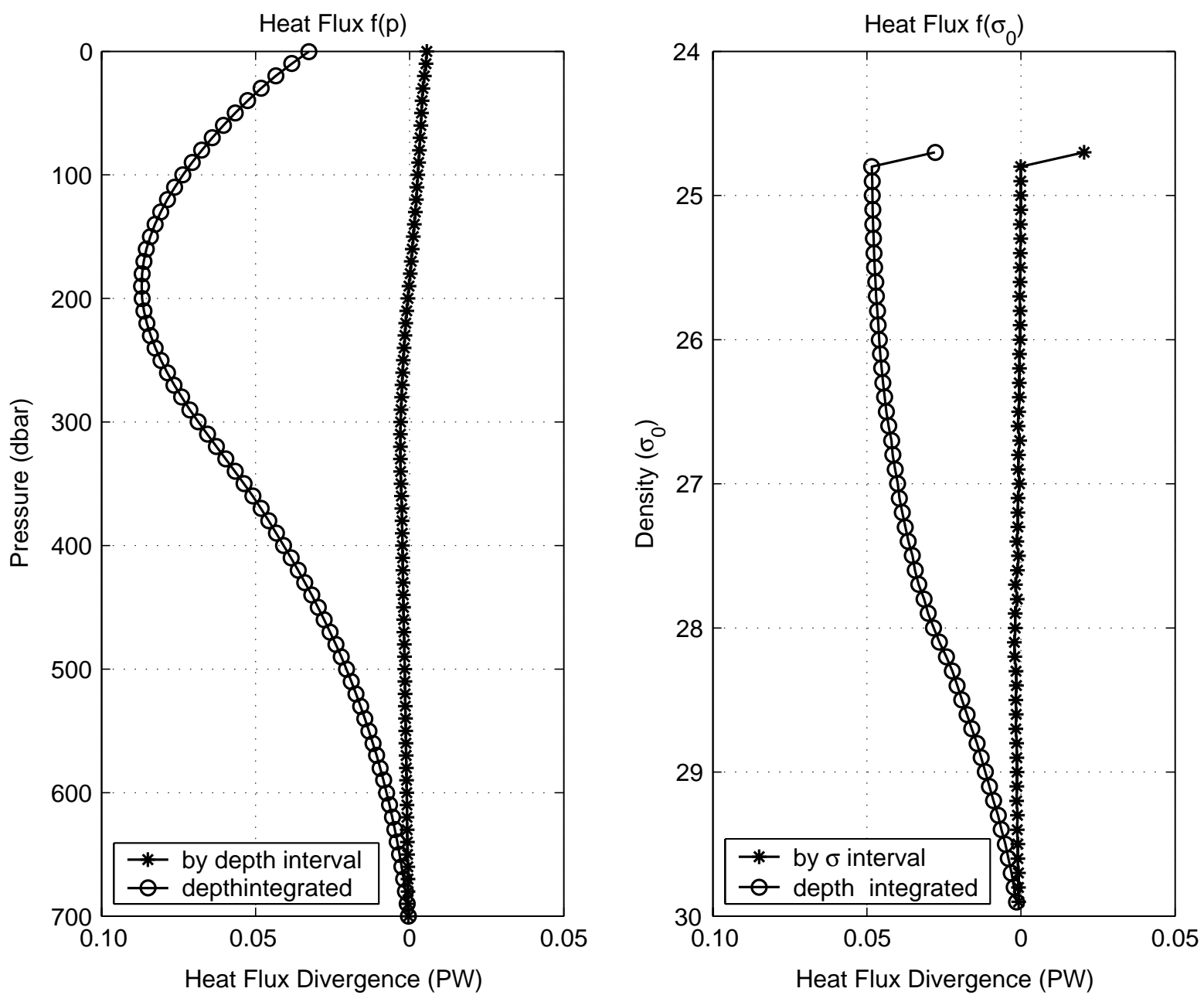

Fig. 8. Results of Indian Ocean heat flux divergence calculation comparing Makassar and Agulhas data, following Profile B interpolation profile for Makassar Strait. Calculations are made along pressure surfaces (a) and along density surfaces (b). Calculation by pressure or density interval are shown by starred line; depth-integrated (cumulative upwards) values are shown by circled line.

it traverses the Indian Ocean, since the surface density in the Agulhas region $\left(23.8 \sigma_{\theta}\right)$ is found at approximately $100 \mathrm{dbar}$ in the Indonesian seas. The latter case represents an adiabatic process.

To calculate the heat flux divergence as a function of pressure we use

$\mathrm{FD}_{p}=c_{p} \int_{700}^{\mathrm{sfc}} V_{\mathrm{M}}\left(\theta_{\mathrm{M}}-\theta_{\mathrm{A}}\right) \sigma_{\theta} \mathrm{d} p$,

where $V_{M}$ is the Makassar Strait volume flux for each pressure interval. The calculation is made along $10 \mathrm{dbar}$ pressure intervals and average values for $V_{\mathrm{M}}, \theta_{\mathrm{M}}, \theta_{\mathrm{A}}$, and $\sigma_{\theta}$ are used for each interval; $c_{p}$ is taken as constant. The depth profile for the divergence calculation made along pressure surfaces is shown in Fig. 8a. The heat flux divergence by pressure bin is shown by starred lines and the depth-integrated (from bottom upward) heat flux divergence is shown by circled lines. The full column heat flux divergence is $-0.04 \mathrm{PW}$ (heat gain by the ITF), essentially $0 \mathrm{PW}$. 
The calculation of heat flux divergence made along density surfaces is almost identical to that made along pressure surfaces, following

$\mathrm{FD}_{\mathrm{d}}=c_{p} \int_{31.9}^{23.9} V_{\mathrm{M}}\left(\theta_{\mathrm{M}}-\theta_{\mathrm{A}}\right) \sigma_{\theta} \mathrm{d} \sigma_{\theta}$.

Average values for $V_{\mathrm{M}}, \theta_{\mathrm{M}}, \theta_{\mathrm{A}}$ are found along each $0.1 \sigma_{\theta}$ increment. The depth profile of Indian Ocean heat flux divergence due to the ITF for the adiabatic assumption is shown in Fig. 8b. Below the surface, the greatest flux divergence is $7.2 \times 10^{12} \mathrm{~W}$ between 28.1 and $28.2 \sigma_{\theta}$. The maximum positive heat flux divergence of $2.3 \times 10^{13} \mathrm{~W}$ is found in the surface density layer, between $23.9 \sigma_{\theta}$ and $24.1 \sigma_{\theta}$. The sum of the full-column heat flux divergence is $-0.03 \mathrm{PW}$, also essentially $0 \mathrm{PW}$.

We have calculated the heat flux divergence of the ITF within the Indian Ocean assuming that all temperature change of the ITF between the Timor Sea and $30^{\circ} \mathrm{S}$ is due to heat exchange with the atmosphere, yielding a maximum estimate of heat flux divergence of the ITF.

Measuring heat transport across a single section within the complex Indonesian seas and taking that point as equivalent to the heat transport at the point where the ITF exits into the Indian Ocean comes with caveats. Although most of the throughflow transits the Makassar Strait as explained in Section 1, there is a possibility that the throughflow heat content is significantly altered between the measurement point within the Makassar Strait and the outflow area in the Timor Sea basin. However, a simple calculation will show that any heat gained between the Makassar Strait and the outflow is insignificant. The distance of ITF travel between the MAK-1 mooring and the outflow (say, $13^{\circ} \mathrm{S}, 120^{\circ} \mathrm{E}$ ) is approximately $2500 \mathrm{~km}$. The approximate annual climatological net radiation input in the southern Makassar and Banda Sea is $140 \mathrm{~W} \mathrm{~m}^{-2}$, according to Oberhuber (1988) heat flux and surface radiation climatology. At $10 \mathrm{~Sv}$ of flow and transit time of 100 days (based on average $0.3 \mathrm{~m} \mathrm{~s}^{-1}$ current speed) the ITF picks up $4.8 \times 10^{9} \mathrm{~W}$, many orders of magnitude less than the heat transported through the Makassar Strait (about $\left.0.5 \times 10^{15} \mathrm{~W}\right)$. As discussed earlier, ITF contribu- tions from sources other than the Makassar Strait are concentrated at depth and so do not factor in the heat calculation.

\section{Discussion and concluding remarks}

An estimate of the heat transport of the Indonesian Throughflow (ITF) based on direct mooring measurements in the Makassar Strait are made. Different flow profiles and reference temperatures constrain possible values of heat transport. For Profile A (maximum upper-level flows), the ITF transported $0.72 \mathrm{PW}$ when referenced to $0{ }^{\circ} \mathrm{C}$ and transported $0.54 \mathrm{PW}$ when referenced to $4^{\circ} \mathrm{C}$ between December 1996 and July 1998 (Table 2). For Profile C (minimum upper level flows), the ITF transported $0.34 \mathrm{PW}$ when referenced to $0^{\circ} \mathrm{C}$ and transported $0.23 \mathrm{PW}$ when referenced to $4^{\circ} \mathrm{C}$ (Table 2). The mean of Profiles $\mathrm{B}$ and D (intermediate flow profile and seasonalmixed profile, respectively) is $0.55 \mathrm{PW}$ at $0^{\circ} \mathrm{C}$ reference temperature and $0.41 \mathrm{PW}$ at $4^{\circ} \mathrm{C}$ reference temperature (Table 2).

These values are significantly lower than values described by most model studies of the throughflow (Table 3), although the numbers are not always directly comparable and there is strong ENSO influence on transport and thermocline depth. A strong El Niño event dominated the period of measurement, possibly leading to volume and heat transports lower than the climatological mean.

While roughly $0.5 \mathrm{PW}$ of heat is advected through the Makassar Strait relative to $0^{\circ} \mathrm{C}$ reference temperature (Profile $\mathrm{B}$ and $\mathrm{D}$ mean), the heat flux divergence north of $30^{\circ} \mathrm{S}$ in the Indian Ocean of the Indonesian Throughflow is effectively 0 PW. Were it to exit the Indian Ocean at Agulhas sea-surface temperatures, the ITF would gain about $0.3 \mathrm{PW}$ of heat. Alternatively, were the ITF to exit within the Agulhas Current after being cooled to the coldest wintertime Indian Ocean SST, it would lose about $0.1 \mathrm{PW}$ of heat. Both cases require significant diapycnal exchange of heat. In a more realistic scenario, the ITF does not experience significant diapycnal heat exchange while transiting the Indian Ocean. If correct, the 
ITF transports a majority of its $0.5 \mathrm{PW}$ of heat out of the Indian Ocean basin south of $30^{\circ} \mathrm{S}$. This is consistent with recent inverse solutions of the Indian Ocean circulation using WOCE hydrographic data. Macdonald and Wunsch (1996) find a large poleward temperature flux of greater than $1 \mathrm{PW}$ across $30^{\circ} \mathrm{S}$ in the Indian Ocean basin. However, they find in their inverse solutions that the strength of the ITF (and thus the heat transport of the ITF into the Indian Ocean) does not affect significantly the Indian Ocean temperature flux across $30^{\circ} \mathrm{S}$. Ganachaud et al. (2000) estimate $15 \pm 5 \mathrm{~Sv}$ and $1.36 \pm 0.15 \mathrm{PW}$ of ITF input into the Indian Ocean but only $0.1 \pm 0.2 \mathrm{PW}$ net heat gain within the Indian Ocean north of $32^{\circ} \mathrm{S}$ due to the ITF. This is also consistent with results from the HadCM3 model (Banks, 2000). When the ITF contribution to the Indian Ocean heat flux is calculated as the divergence of temperature fluxes between the Indonesian seas and $32^{\circ} \mathrm{S}$, Banks (2000) finds 0.13 PW Indian Ocean heat gain. When calculated as the difference in surface heat fluxes between $32^{\circ} \mathrm{S}$ and the Indonesian seas, the Indian Ocean heat gain is $0.03 \mathrm{PW}$. The difference is attributed to cooling of the volume-averaged temperature of the Indian Ocean over the model run. Garternicht and Schott (1997) find similar results using the $1 / 4^{\circ}$ Semtner/Chervin global eddy-resolving model. In their model the ITF introduces $0.90 \mathrm{PW}$ of heat into the Indian Ocean. Their annual average meridional temperature flux across $30^{\circ} \mathrm{S}$ due to the ITF is $-0.91 \mathrm{PW}$. The ITF therefore loses $0.01 \mathrm{PW}$ of heat while in the Indian Ocean.

The ITF heat transport imported to the Indian Ocean (using Profile D with a reference temperature of $3.4^{\circ} \mathrm{C}$, Table 2) is $0.41 \mathrm{PW}$, which is well above the $0.1 \mathrm{PW}$ estimated error for heat flux calculations (see for example Ganachaud et al., 2000). If this $0.41 \mathrm{PW}$ of heat from the ITF were spread across the surface and lost to the atmosphere over the Indian Ocean north of $30^{\circ} \mathrm{S}$, the sea-air heat flux would be $11.7 \mathrm{~W} \mathrm{~m}^{-2}$. As the mean sea-air heat flux (see Fig. 1.7 of Tomczak and Godfrey, 1994 ) is about $40 \mathrm{~W} \mathrm{~m}^{-2}$ north of $10^{\circ} \mathrm{S}$, and close to zero between $10^{\circ} \mathrm{S}$ and $30^{\circ} \mathrm{S}$, the ITF has the potential of providing a significant portion (up to $25 \%$ ) of the total sea-air heat flux budget of the Indian Ocean. However, it is clearly unrealistic to assume that all of the ITF water cools by sea-air heat flux to $3.4^{\circ} \mathrm{C}$ north of $30^{\circ} \mathrm{S}$ in the Indian Ocean. The range of ITF heat divergence from our minimum to maximum reasonable scenarios is $-0.28 \mathrm{PW}$ to $+0.11 \mathrm{PW}$ (or a sea-air heat flux of -8.0 and $+3.1 \mathrm{~W} \mathrm{~m}^{-2}$, respectively). Such numbers are only slightly greater than the estimated uncertainty. Our conclusion is clear: the ITF heat divergence in the Indian Ocean north of $30^{\circ} \mathrm{S}$ is small, hardly above the estimated uncertainty in various calculations of heat transport.

When the Indonesian Throughflow is included in global runs, model studies show large heat loss in the Agulhas retroflection region and in the Antarctic Circumpolar Current (ACC) eastward of the southern tip of Africa, but little heat loss within the Indian Ocean (Hirst and Godfrey, 1993; Hirst and Godfrey, 1994; Allan et al., 1995). When heat flux is calculated in model runs comparing closed and open Indonesian passages, the most striking differences are centered at the Agulhas outflow off southeast Africa, centered at $40^{\circ} \mathrm{S}$, $30^{\circ} \mathrm{E}$ (see Fig. 16 of Allan et al., 1995, which is calculated from the Hirst and Godfrey, 1993, runs). Our results are consistent with these conclusions. It is quite surprising that the ITF would import a large amount of heat into the Indian Ocean without losing that heat while residing within the Indian Ocean. The ITF can be seen as a crucial component to heat transfer from the equatorial Pacific to the southwestern Indian Ocean, about 10,000 km away (great circle route).

\section{Acknowledgements}

The research is funded by the Office of Naval Research (N00014-97-1-0722, N00014-98-1-0270) and the National Science Foundation (OCE9729322, OCE00-99152). We appreciate the support, technical advice and patience of Phil Mele, Bruce Huber and Claudia Giulivi. Lamont-Doherty Contribution Number 6202. 


\section{References}

Allan, R.J., Lindesay, J.A., Reason, C.J.C., 1995. Multidecadal variability in the climate system over the Indian Ocean region during the Austral summer. Journal of Climate 8, 1853-1873.

Banks, H.T., 2000. Indonesian throughflow in a coupled climate model and the sensitivity of the heat budget and deep overturning. Journal of Geophysical Research 105, 26135-26150.

Beal, L.M., Bryden, H.L., 1999. The velocity and vorticity structure of the Agulhas Current at $32^{\circ} \mathrm{S}$. Journal of Geophysical Research 104, 5151-5176.

Bray, N.A., Hautala, S., Chong, J.C., Pariwono, J., 1996. Large-scale sea level, thermocline, and wind variations in the Indonesian throughflow region. Journal of Geophysical Research 101, 12239-12254.

Conkright, M.E., Levitus, S., O'Brien, T., Boyer, T.P., Antonov, J.I., Stephens, C., 1998. World Ocean Atlas 1998 CD-ROM Data Set Documentation. National Oceanic Data Center, NODC Internal Report 15, 16pp.

Ffield, A., Gordon, A.L., 1992. Vertical mixing in the Indonesian thermocline. Journal of Physical Oceanography 22, 184-195.

Ffield, A., Vranes, K., Gordon, A.L., Susanto, R.D., Garzoli, S.L., 2000. Temperature variability within Makassar Strait. Geophysical Research Letters 27, 237-240.

Fieux, M., Andrie, C., Delecluse, P., Ilahude, A.G., Kartavtseff, A., Mantisi, F., Molcard, R., Swallow, J.C., 1994. Measurements within the Pacific-Indian oceans throughflow region. Deep-Sea Research Part I 41, 1091-1130.

Fieux, M., Molcard, R., Ilahude, A.G., 1996. Geostrophic transport of the Pacific-Indian Oceans throughflow. Journal of Geophysical Research 101, 12421-12432.

Fine, R.A., 1985. Direct evidence using tritium data for throughflow from the Pacific into the Indian Ocean. Nature $315,478-480$.

Ganachaud, A., Wunsch, C., 2000. Improved estimates of global ocean circulation, heat transport and mixing from hydrographic data. Nature 408, 453-457.

Ganachaud, A., Wunsch, C., Marotzke, J., Toole, J.M., 2000. Meridional overturning and large-scale circulation of the Indian Ocean. Journal of Geophysical Research 105, 26117-26134.

Garternicht, U., Schott, F., 1997. Heat fluxes of the Indian Ocean from a global eddy-resolving model. Journal of Geophysical Research 102, 21147-21159.

Godfrey, J.S., 1989. A Sverdrup model of the depth-integrated flow for the world ocean allowing for island circulations. Geophysical and Astrophysical Fluid Dynamics 45, 89-112.

Godfrey, J.S., 1996. The effect of the Indonesian throughflow on ocean circulation and heat exchange with the atmosphere: A review. Journal of Geophysical Research 101, 12217-12238.

Godfrey, J.S., Ridgway, K.R., 1985. The large-scale environment of the poleward-flowing Leeuwin Current, western Australia: longshore steric height gradients, wind stresses and geostrophic flow. Journal of Physical Oceanography 15, 481-495.

Gordon, A.L., 1986. Interocean exchange of thermocline water. Journal of Geophysical Research 91, 5037-5046.

Gordon, A.L., 2001. Interocean Exchange. In: Siedler, G., Church, J., Gould, J. (Eds.), Ocean Circulation and Climate. Academic Press, San Diego, 640pp.

Gordon, A.L., Fine, R.A., 1996. Pathways of water between the Pacific and Indian Oceans in the Indonesian Seas. Nature 379, 146-149.

Gordon, A.L., McClean, J.L., 1999. Thermocline stratification of the Indonesian Seas - models and observations. Journal of Physical Oceanography 29, 198-216.

Gordon, A.L., Susanto, R.D., 1999. Makassar Strait transport: initial estimate based on Arlindo results. MTS Journal 32, 34-45.

Gordon, A.L., Lutjeharms, J.R.E., Grundlingh, M.L., 1987. Stratification and circulation at the Agulhas retroflection. Deep-Sea Research I 34, 565-599.

Gordon, A.L., Ffield, A., Ilahude, A.G., 1994. Thermocline of the Flores and Banda Seas. Journal of Geophysical Research 99, 18235-18242.

Gordon, A.L., Ma, S., Olson, D.B., Hacker, P., Ffield, A., Talley, L.D., Wilson, D., Baringer, M., 1997. Advection and diffusion of Indonesian throughflow water within the Indian Ocean South Equatorial Current. Geophysical Research Letters 24, 2573-2576.

Gordon, A.L., Susanto, R.D., Ffield, A., Pillsbury, D., 1998. Makassar Strait transport: preliminary Arlindo results from Mak-1 and Mak-2. International WOCE Newsletter 33, $30-32$.

Gordon, A.L., Susanto, R.D., Ffield, A., 1999. Throughflow within Makassar Strait. Geophysical Research Letters 26, 3325-3328.

Hall, M.M., Bryden, H.L., 1982. Direct estimates and mechanisms of ocean heat transport. Deep-Sea Research I 29, 339-359.

Hautala, S., Reid, J.L., Bray, N.A., 1996. The distribution and mixing of Pacific Water masses in the Indonesian Seas. Journal of Geophysical Research 101, 12375-12390.

Hirst, A.C., Godfrey, J.S., 1993. The role of Indonesian throughflow in a global ocean GCM. Journal of Physical Oceanography 23, 1057-1086.

Hirst, A.C., Godfrey, J.S., 1994. The response to a sudden change in Indonesian throughflow in a global ocean GCM. Journal of Physical Oceanography 24, 1895-1910.

Ilahude, A.G., Gordon, A.L., 1996. Thermocline stratification within the Indonesian Seas. Journal of Geophysical Research 101, 12401-12409.

Lebedev, K.V., Yaremchuk, M.I., 2000. A diagnostic study of the Indonesian Throughflow. Journal of Geophysical Research 105, 11243-11258.

Lukas, R., Yamagata, T., McCreary, J.P.J., 1996. Pacific lowlatitude western boundary currents and the Indonesian throughflow. Journal of Geophysical Research 101, 12209-12216. 
Macdonald, A.M., 1993. Property fluxes at $30^{\circ} \mathrm{S}$ and their implications for the Pacific-Indian throughflow and the global heat budget. Journal of Geophysical Research 98, 6851-6868.

Macdonald, A.M., Wunsch, C., 1996. An estimate of global ocean circulation and heat fluxes. Nature 382, 436-439.

Mariano, A.J., Ryan, E.H., Perkins, B.D., Smithers, S., 1995. The Mariano global surface velocity analysis 1.0. United States Coast Guard, CG-D-34-95, 55pp.

Meyers, G., 1996. Variation of Indonesian throughflow and the El Nino-Southern Oscillation. Journal of Geophysical Research 101, 12255-12263.

Molcard, R., Fieux, M., Ilahude, A.G., 1996. The Indo-Pacific throughflow in the Timor Passage. Journal of Geophysical Research 101, 12411-12420.

Molcard, R., Fieux, M., Syamsudin, F., 2001. The throughflow within Ombai Strait. Deep-Sea Research I 48 (5), 1237-1253.

Murray, S.P., Arief, D., 1988. Throughflow into the Indian Ocean through the Lombok Strait, January 1985-January 1986. Nature 333, 444-447.

Masumoto, Y., Yamagata, T., 1996. Seasonal variations of the Indonesian Throughflow in a general ocean circulation model. Journal of Geophysical Research 101, 12287-12293.

Oberhuber, J.M., 1988. An atlas based on 'COADS' data set. Max-Planck-Instutut für Meteorologie, Technical Report 15.

Qiu, B., Mao, M., Kashino, Y., 1999. Intraseasonal variability in the Indo-Pacific Throughflow and the regions surrounding the Indonesian seas. Journal of Physical Oceanography 29, 1599-1618.

Piola, A., Gordon, A., 1984. Pacific and Indian Ocean upperlayer salinity budget. Journal of Physical Oceanography 14, 747-753.

Potemra, J.T., 1999. Seasonal variations of upper ocean transport from the Pacific to the Indian Ocean via Indonesian straits. Journal of Physical Oceanography 29, 2930-2944.

Potemra, J.T., Lukas, R., Mitchum, G.T., 1997. Large-scale estimation of transport from the Pacific to the Indian Ocean. Journal of Geophysical Research 102, 27795-27812.

Read, J.F., Pollard, R.T., 1993. Structure and transport of the Antarctic Circumpolar Current and Agulhas Return Current at 40E. Journal of Geophysical Research 98, 12281-12295.

Robbins, P.E., Toole, J.M., 1997. The dissolved silica budget as a constraint on the meridional overturning circulation of the Indian Ocean. Deep-Sea Research Part I 44, 879-906.

Rochford, D.J., 1961. Hydrology of the Indian Ocean. I. The water masses in intermediate depths of the south-east Indian Ocean. Australian Journal of Marine Freshwater Research 12, 129-149.

Schiller, A., Godfrey, J.S., McIntosh, P.C., Meyers, G., Wijffels, S.E., 1998. Seasonal near-surface dynamics and thermodynamics of the Indian Ocean and Indonesian
Throughflow in a global ocean general circulation model. Journal of Physical Oceanography 28, 2288-2312.

Schmitz Jr., W.J., 1995. On the interbasin-scale thermohaline circulation. Reviews of Geophysics 33, 151-173.

Schneider, N., Barnett, T.P., 1997. Indonesian throughflow in a coupled general circulation model. Journal of Geophysical Research 102, 12341-12358.

Shriver, J.F., Hurlburt, H.E., 1997. The contribution of the global thermohaline circulation to the Pacific to Indian Ocean throughflow via Indonesia. Journal of Geophysical Research 102, 5491-5511.

Sprintall, J., Gordon, A.L., Murtugudde, R., Susanto, R.D., 2000. A semiannual Indian Ocean forced Kelvin wave observed in the Indonesian seas in May 1997. Journal of Geophysical Research 105, 17217-17230.

Stammer, D., 1998. On eddy characteristics, eddy transports, and mean flow properties. Journal of Physical Oceanography 28, 727-739.

Susanto, R.D., Gordon, A.L., Sprintall, J., Herunadi, B., 2000. Intraseasonal variability and tides in Makassar Strait. Geophysical Research Letters 27, 1499-1502.

Tomczak, M., Godfrey, J.S., 1994. Regional Oceanography: An Introduction. Pergamon, London, 422pp.

Toole, J.M., Raymer, M.E., 1985. Heat and fresh water budgets of the Indian Ocean-revisited. Deep-Sea Research I 32, 917-928.

Toole, J.M., Warren, B.A., 1993. A hydrographic section across the subtropical South Indian Ocean. Deep-Sea Research Part I 40, 1973-2019.

Verschell, M.A., Kindle, J.C., O'Brien, J.J., 1995. Effects of Indo-Pacific throughflow on the upper tropical Pacific and Indian Oceans. Journal of Geophysical Research 100, 18409-18420.

Wajsowicz, R., 1996. Flow of a western boundary current through multiple straits: an electrical circuit analogy for the Indonesian throughflow and archipelago. Journal of Geophysical Research 101, 12295-12300.

Warren, B.A., 1999. Approximating the energy transport across oceanic sections. Journal of Geophysical Research 104, 7915-7919.

Webster, P., Magana, V.O., Palmer, T.N., Shukla, J., Tomas, R.A., Yanai, M., Yasunari, T., 1998. Monsoons: Processes, predictability, and the prospects for prediction. Journal of Geophysical Research 103, 14451-14510.

Wijffels, S., Schmitt, R.W., Bryden, H.L., Stigebrandt, A., 1992. Transport of freshwater by the oceans. Journal of Physical Oceanography 22, 155-162.

Wyrtki, K., 1961. Physical oceanography of the Southeast Asian waters, scientific results of maritime investigations of the South China Sea and Gulf of Thailand 1959-1961, NAGA Report 2. Scripps Institute of Oceanography, $195 \mathrm{pp}$.

Wyrtki, K., 1987. Indonesian through flow and the associated pressure gradient. Journal of Geophysical Research 92, 12941-12946. 